\title{
Breast Cancer and the Politics of Abortion in the United States
}

\author{
PATRICIA JASEN*
}

Epidemiology, like any branch of medical science, functions within a social and historical context. That context influences what questions are asked, how they are investigated, and how their conclusions are interpreted, both by researchers and by the public. The international debate over whether abortion increases breast cancer risk, which has been the subject of many studies and much heated controversy in recent decades, became so intensely politicized in the United States that it serves as a particularly stark illustration of how elusive the quest for scientific certainty can be. Although a growing interest in reproductive factors and breast cancer risk developed after the Second World War, it was not until the early 1980s, after induced abortion had been legalized in many countries, that studies began to focus on this specific factor. In the US these were the years following Roe $\mathrm{v}$ Wade, when anti-abortionists mounted their counterattack and prochoice forces were on the defensive. As a result, epidemiologists found themselves at the centre of a debate which had come to symbolize a deepening divide in American culture. This paper traces the history of the scientific investigation of the alleged abortion-breast cancer link, against the backdrop of what was increasingly termed an "epidemic" of breast cancer in the US. That history, in turn, is closely intertwined with the anti-abortion movement's efforts, following the violence of the early 1990s, to regain respectability through changing its tactics and rhetoric, which included the adoption of the "ABC link" as part of its new "women-centred" strategy.

\section{Background}

Of all the cancers which afflict the Western world, breast cancer has been the focus of the longest historical controversy over what its causes may be and why some women are more vulnerable to the disease than others. ${ }^{1}$ Common explanations have ranged from blows to the breast to the effect of unhappy emotions, but have also focused on the influence of events in women's reproductive lives. ${ }^{2}$ Opinion was long divided over whether childless women were at greater or lesser risk, and the same controversy surrounded the significance

(C) Patricia Jasen 2005

* Patricia Jasen, PhD, Department of History, Lakehead University, 955 Oliver Road, Thunder Bay, Ontario, Canada P7B 5E1.

For their assistance during the preparation of this paper, I would like to thank Mandy Hadenko, Frederick Holmes, Jaro Kotalik, Judith Leggett, Gillian Siddall, Helen Smith, Pamela Wakewich, and
Rachel Warburton. Research funding was provided by the Social Sciences and Humanities Research Council of Canada.

\footnotetext{
${ }^{1}$ See Daniel de Moulin, A short history of breast cancer, The Hague, Martinus Nijhoff, 1983.

${ }^{2}$ See Patricia Jasen, 'Breast cancer and the language of risk, 1750-1950', Soc. Hist. Med., 2002, 15: $17-43$.
} 


\section{Patricia Jasen}

of breast-feeding. ${ }^{3}$ More definitive answers awaited the improvement of data collection and analysis as the field of epidemiology developed in the twentieth century. The first study to include both a large group of breast cancer patients and a control group of healthy women was conducted in Britain in the 1920s by Janet Lane-Claypon, and she found consistent differences between the two groups in relation to age at marriage, fertility, and lactation. ${ }^{4}$ She also posited that lifetime exposure to oestrogen was a significant factor, and, by the 1940s, endocrinologists were paying closer attention to the role of hormones in breast cancer. ${ }^{5}$

The study of reproductive factors in relation to breast cancer continued after the Second World War, as researchers expanded the number of variables taken into consideration, including the use of hormone replacement therapy and, by the mid-1960s, the use of oral contraceptives. Even though attention was not focused on abortion until the early 1980s, it also began to receive brief mention as a possible risk factor. The earliest study cited in the epidemiological literature dates back to the 1950s, when researchers in the Department of Public Health at Tohoku University Medical School published a wide-ranging study of all common cancers in Japan. They found slightly higher rates of spontaneous abortion and significantly higher rates of induced abortion among cancer patients, but were hesitant to draw any firm conclusions because of methodological weaknesses in their study. Although their cautionary comments were usually ignored by later researchers when citing their report, the Tohoku team were explicit about their concern that the women in the control group, who were not facing a life-threatening disease, were less likely to report a past history of induced abortion, thus making it impossible to draw any conclusions about a cancer link. ${ }^{6}$ In later years, this phenomenon would be referred to as "recall bias".

Intensive research into the role abortion might play in breast cancer risk would not begin for another quarter century but, during the intervening years, the legal status of the procedure changed in many countries, making it possible for the subject to be discussed more openly, and for more accurate statistical records to be kept. By far the greatest controversy surrounding this area of research would develop in the US, where the debate over abortion was passionate and deeply divisive. Prior to 1973 , abortion was illegal in thirty US states, with the exception of cases where the life of the mother was in danger, while in at least a dozen others abortion was permitted only in cases of rape or incest, or if the fetus suffered severe abnormalities. ${ }^{7}$ Abortion law was thus very inconsistent from one

\footnotetext{
${ }^{3}$ For differing views among nineteenth-century authorities, see Walter $\mathrm{H}$ Walshe, The nature and treatment of cancer, London, Taylor and Walton, 1846, p. 154; W Roger Williams, A monograph on diseases of the breast, their pathology and treatment, with special reference to cancer, London, John Bale, 1894, pp. 287-8; William Rodman, Diseases of the breast with special reference to cancer, Philadelphia, Blakiston, 1908, pp. 181-2; Willard Parker, Cancer: a study of three hundred and ninety-seven cases of cancer of the female breast, New York, Putnam, 1885 , p. 22.

${ }^{4}$ De Moulin, op. cit., note 1 above, pp. 89-90.
}

\footnotetext{
${ }^{5}$ See Ira T Nathanson, 'The relationship of hormones to diseases of the breast', in G H Twombly and G T Pack (eds), Endocrinology of neoplastic diseases: a symposium by eighteen authors, New York, Oxford University Press, 1947, pp. 138-78.

${ }^{6}$ M Segi, I Fukushima, S Fujisaku, M Kurihara, S Saito, K Asano, and M Kamoi, 'An epidemiological study on cancer in Japan', GANN: Japanese Journal of Cancer Research, 1957, 48 (Supplement), p. 42.

${ }^{7}$ James Risen and Judy L Thomas, Wrath of angels: the American abortion war, New York, Basic Books, 1998 , p. 36.
} 


\section{Breast Cancer and the Politics of Abortion in the United States}

jurisdiction to another; in some states, even providing information on how to obtain an abortion elsewhere could lead to arrest. ${ }^{8}$ Challenges to abortion laws across the US eventually led to the sweeping decision by the Supreme Court on 22 January 1973. While Roe v Wade did not recognize a woman's "absolute right" to an abortion under the Constitution, it allowed (but did not require) states to regulate abortion only after the fetus was viable (i.e. in the third, or in some cases the second, trimester). By 1980, over one and half million abortions were being reported each year. The majority of them were performed in freestanding clinics, which mushroomed even in the weeks that followed Roe v Wade. ${ }^{9}$

The ruling brought an immediate reaction from opponents of abortion. As James Risen and Judy Thomas explain, even some pro-choice advocates, such as SC Justice Ruth Bader Ginsburg, believed that Roe v Wade "went too far, too fast, taking a giant leap the country was not prepared to make". ${ }^{10}$ The battle had only begun, and would now become closely tied to a major transformation in American religious and political life during the last quarter of the century, for the anti-abortion movement grew very much in tandem with the rise of evangelical Christianity in the United States. Before abortion was legalized, the Roman Catholic hierarchy had been the force behind most of the lobbying but, following Roe $\mathrm{v}$ Wade, they were joined by increasingly militant, and increasingly numerous, Protestant fundamentalists dedicated to the anti-abortion cause. Although the drift towards direct action strategies had its origins in the tactics of Catholic leftists of the 1960s, Christian fundamentalism would soon transform "civil disobedience into a conservative tool" and become associated with right-wing politics and opinion. ${ }^{11}$ Of even greater significance, however, was the grassroots, anti-establishment nature of that conservatism. Anti-abortionists discovered that conservatives in high places could not necessarily be counted upon, and their leaders, like their preachers, were drawn from the ranks of ordinary Americans, so that the increasingly apocalyptic rhetoric of the movement was infused with a strongly populist impulse. Christian revivalism, fused with "pro-life" activism, strove for the awakening of all of America to "the horrors, the evil, and the truth of abortion". ${ }^{12}$

\section{Abortion-Breast Cancer Research to 1994}

When research into a possible link between abortion and breast cancer began in earnest in the early 1980s, there was no hint that, within a few short years, epidemiologists would be thrust into the wider debate over abortion in the US. The first published studies represented a growing interest in an aspect of women's reproductive lives which could now be reported and discussed more openly, and they were part of an expanding international dialogue in which American researchers took a very active part. This section of the paper will examine the tentative and conflicting conclusions reached during the $1980 \mathrm{~s}$ and early 1990s, but will first consider how some earlier studies were used to provide a

\footnotetext{
${ }^{8}$ Cynthia Gorney, Articles of faith: a frontline history of the abortion wars, New York, Simon and Schuster, 1998, pp. 151-2.

${ }^{9}$ Risen and Thomas, op. cit., note 7 above, pp. 15-16, 36, 106.

${ }^{10}$ Ibid., pp. 37-9.
}

\footnotetext{
${ }^{11}$ Ibid., pp. 19, 39-40.

${ }^{12}$ Carol Mason, Killing for life: the apocalyptic narrative of pro-life politics, Ithaca, Cornell University Press, 2002, p. 2; see also Kerry N Jacoby, Souls, bodies, spirits: the drive to abolish abortion since 1973, Westport, CT, Praeger, 1998, p. 154.
} 


\section{Patricia Jasen}

foundation for later work. It should be noted that the common means of conveying results throughout this literature was to indicate the degree of "relative risk" (RR) posed by abortion. For example, a relative risk of 1.5 suggests that women who have had abortions have a 50 per cent higher risk than other women, when all other factors have been controlled. The meaningfulness of such figures depends on many elements, including the ability of researchers to separate abortion from confounds and from other risk factors, the appropriateness of the control group, the numbers of women in the study, the accuracy of reporting abortions, and the extent to which low levels of relative risk (below $\mathrm{RR}=2.0$ ) can be considered significant.

In epidemiological literature, when interest in a potential risk factor is developing, its possible significance sometimes gains credibility from early, tentative evidence which seems to provide some shaky support for the hypothesis being tested. In this manner, a historical process begins, common in scientific research, whereby these early studies are cited again and again, without due attention to the context in which they were conducted, the validity of their results, or even the precise nature of their conclusions. This was very much the case with the abortion-breast cancer debate. The early Japanese study was often cited in support of a link, and much weight was given to a series of international studies on breast cancer epidemiology conducted during the late 1960s by Brian MacMahon in collaboration with researchers in both eastern Europe and Asia. ${ }^{13}$ They investigated a wide range of reproductive factors, but abortion did receive brief mention in each study. The findings were inconsistent, and in one study fewer abortions than expected or predicted were reported by women who had become cancer patients. ${ }^{14}$ But when MacMahon and his co-authors summarized these results in a much cited article published by the American Journal of the National Cancer Institute in 1973, they inaccurately concluded that, even though abortion was not consistently linked to cancer, "where a relationship was observed, abortion was associated with increased, not decreased, risk". 15

Proceeding from an understanding (derived from MacMahon, et al.) that abortion was an already established risk factor for human breast cancer, Jose and Irma Russo of the Michigan Cancer Foundation in Detroit set out in 1978 to discover the mechanism behind this link. They introduced carcinogens into rats in order to investigate the influence of pregnancy interruption, compared with full pregnancy and lactation, on tumour development. Their study supported the theory that structural changes in breast tissue are responsible for the lasting, protective effect of full-term pregnancy. They observed that abortion left the rats highly susceptible to developing cancer, but that the aborted rats "were at the same risk as virgin animals treated with the carcinogen" 16 (italics mine). Over the next two decades, however, their findings would be cited repeatedly as evidence that pregnancy

\footnotetext{
${ }^{13}$ V G Valoras, B MacMahon, D Trichopoulos and A Polychronopoulou, 'Lactation and reproductive histories of breast cancer patients in Greater Athens, 1965-67', Int. J. Cancer, 1969, 4: 350-63; S Yuasa and B MacMahon, 'Lactation and reproductive histories of breast cancer patients in Tokyo, Japan', Bull. WHO, 1970, 42: 195-204; T M Lim, K P Chen, and B MacMahon, 'Epidemiologic characteristics of cancer of the breast in Taiwan', Cancer, 1971, 27: 1497-1504; B Ravnihar, B MacMahon and
}

J Lindtner, 'Epidemiologic features of breast cancer in Slovenia, 1965-67', Eur. J. Cancer, 1971, 7: 295-306.

${ }^{14}$ Ravnihar, et al., op. cit., note 13 above, p. 301.

${ }^{15} \mathrm{~B}$ MacMahon, P Cole, and J Brown, 'Etiology of human breast cancer: a review', J. Nat. Cancer Inst., 1973, 50: 21-42, on p. 22.

${ }^{16}$ Jose Russo and Irma H Russo, 'Susceptibility of the mammary gland to carcinogenesis', Am. J. Pathol., 1980, 100: 497-512, on pp. 497-8. 


\section{Breast Cancer and the Politics of Abortion in the United States}

begins a process of breast change which, when stopped by abortion, put female rats (and thus humans) at greater risk of cancer than those who had never been pregnant. ${ }^{17}$

The Russo study was published in 1980, and an international dialogue among researchers focused on the abortion-breast cancer question commenced in the British Journal of Cancer shortly thereafter. It began with a study conducted by Malcolm Pike and colleagues at the University of Southern California. Their objective was to determine the influence of both oral contraceptive use and early abortion, and, because oral contraceptives had only been in common use for just over a decade, they looked at younger women only-all 163 of their cases had been diagnosed with breast cancer by the time they were 32 years of age. ${ }^{18}$ Despite the methodological problems inherent in this study, it gained long-lasting attention because of its finding that women who had a first trimester induced or spontaneous abortion before their first full-term pregnancy (often abbreviated as FFTP) had almost a two and a half times greater risk of breast cancer $(R R=2.4)$ than women who had no abortions. A later pregnancy reduced that level of risk, and abortions occurring after the first trimester or after a FFTP carried no increased risk at all. Pike and his colleagues saw their study as the first to report a "substantial increase in risk" specifically associated with early abortion, and, in light of the growing abortion rate among young women in many countries, they predicted their findings would be "of major importance". ${ }^{19}$ The gauntlet had been thrown down, and a British research team, already engaged in a long-term study of reproductive factors in breast cancer patients treated at London and Oxford hospitals, responded immediately to Pike's "provocative and worrying results". ${ }^{20}$ But in contrast to Pike, they found no increase in risk associated with either oral contraceptive use or abortion, and attributed this outcome to differences in methodologies and the "effect of chance". 21

Conflicting results, and conflicting interpretations of results, would characterize the abortion-breast cancer debate as it intensified throughout the decade. An international array of cancer and epidemiological journals published studies which variously demonstrated an increased risk, no evidence of risk, and even decreased risk of cancer following abortion. $^{22}$ The interpretation of statistical findings was inconsistent as well, for a certain

\footnotetext{
${ }^{17}$ For an example of the continuing use of this study, see Barry Yeoman, 'The scientist who hated abortion and did something about it', Discover, Feb. 2003, 24: 54-9, on p. 56.

${ }^{18}$ M C Pike, B E Henderson, J T Casagrande, I Rosario, and G E Gray, 'Oral contraceptive use and early abortion as risk factors for breast cancer in young women', Br. J. Cancer, 1981, 43: 72-6, on p. 72.

${ }^{19}$ Ibid., pp. $75-6$.

${ }^{20}$ M P Vessey, K McPherson, D Yeates, and $\mathrm{R}$ Doll, 'Oral contraceptive use and abortion before first term pregnancy in relation to breast cancer risk', Br. J. Cancer, 1982, 45: 327-31, on p. 327.

${ }^{21}$ Ibid., pp. $330-1$, on p. 330.

${ }^{22}$ M Ewertz and S W Duffy, 'Risk of breast cancer in relation to reproductive factors in Denmark', Br. J. Cancer, 1988, 58: 99-104, reported an increased risk in nulliparous women; and H Howe, R T Senie, $\mathrm{H}$ Bzduch, and P Herzfeld, 'Early abortion and breast
}

cancer risk of women under age 40', Int. J. Epidemiol., 1989, 18: 300-4, reported an almost doubled risk among women with induced abortions. Studies which concluded that abortion did not result in a statistically significant elevation in risk include S P Helmrich, S Shapiro, L Rosenberg, D Kaufman, D Slone, C Bain, O Miettinen, P D Stolley, N Rosenshein, R C Knapp, T Leavitt Jr., D Schottenfeld, R. Engle Jr., and M Levy, 'Risk factors for breast cancer', Am. J. Epidemiol., 1983, 117: 35-45; C La Vecchia, A Decarli, F Parazzini, A Gentile, E Negri, G Cecchetti, and S Franceschi, 'General epidemiology of breast cancer in northern Italy', Int. J. Epidemiol., 1987, 16: 347-55;

L Rosenberg, J R Palmer, D W Kaufman, B L Strom, D Schottenfeld, and S Shapiro, 'Breast cancer in relation to the occurrence and time of induced and spontaneous abortion', Am. J. Epidemiol., 1988, 127 981-9; B-M Lindefors Harris, G Eklund, O Meirik, 


\section{Patricia Jasen}

level of risk (usually in the range of $\mathrm{RR}=1.2$ to 1.5 ) was considered significant by some and not by others - an issue still hotly debated in recent years, and part of the reason why some of the same studies have been used as supporting evidence by opposing sides in the debate. Some reported that miscarriage was associated with a lesser risk (or even a negative risk) in comparison with induced abortion, while a much publicized study of Connecticut women which included only spontaneous abortion found a 3.5 fold increase in cancer incidence in women who miscarried before their first live birth. ${ }^{23}$ Positive findings also varied with respect to whether abortion posed a danger only if it occurred before the first full-term pregnancy, or only among women who never carried a later pregnancy to term, in which case there was often ambiguity as to whether or not women in the cancer group were being compared only with other nulliparous women. Not unexpectedly, researchers usually drew upon preceding reports which they considered significant in relation to their own findings, with some giving undue weight to studies involving very few women reporting induced abortions or glossing over the inconsistencies which emerge from a closer examination of the data. The great majority of these studies were retrospective, case-control studies, meaning that women were reporting their abortion histories after being diagnosed for breast cancer (rather than before, as in prospective studies). During the 1980s, few researchers openly considered the question of inaccurate reporting of past abortions by participants.

The interest in younger women and cancer, initiated by Pike, persisted throughout this period for a variety of reasons. Records of abortion were more readily available for this age group, and researchers were very conscious of the fact that more and more young women were choosing abortion. There was also some evidence, inconsistent and yet alarming, that breast cancer rates among young women were on the rise; this trend was reported in the US and Sweden, although not in the United Kingdom, and was apparently more pronounced among young African-American women in the US. This last factor attracted the attention of the epidemiologist Janet Daling at the Fred Hutchinson Cancer Research Center in Seattle, Washington, who had already published widely on cancer epidemiology and whose earlier research had examined the implications of abortion for future childbearing. In 1987, she and her colleagues published a study of breast cancer incidence, in relation to age and ethnicity, in the western portion of Washington state. ${ }^{24}$ They observed a 22 per cent increase in breast cancer in women aged 25 to 44 over an eight-year period, a change which could not, they felt, be accounted for by earlier detection or an overall increase in breast cancer rates, as they reported (inaccurately, as they later discovered) a declining incidence for women aged 45 to $54 .{ }^{25}$ They found the greatest increase was

L E Rutqvist, and K Wiklund, 'Risk of cancer of the breast after legal abortion during first trimester: a Swedish registry study', Br. med. J., 9 Dec. 1989 299: 1430-32; and F Parazzini, C La Vecchia, and E Negri, 'Spontaneous and induced abortions and risk of breast cancer', Int. J. Cancer, 1991, 48: 816-20. R S Paffenbarger Jr, J B Kampert, H-G Chang, 'Characteristics that predict risk of breast cancer before and after the menopause', Am. J. Epidemiol., 1980 , 112: $258-68$, found that risk was slightly lowered.
${ }^{23}$ O C Hadjimichael, C A Boyle, and J W Meigs, 'Abortion before first livebirth and risk of breast cancer', Br. J. Cancer, 1986, 53: 281-4.

${ }^{24}$ E White, J R Daling, T L Norsted, and J Chu, 'Rising incidence of breast cancer among young women in Washington state', J. Nat. Cancer Inst., Aug. 1987, 79: 239-43, on p. 241.

${ }^{25}$ This misconception was later corrected; see P Velentgas and J R Daling, 'Risk factors for breast cancer in younger women', J. Nat. Cancer Inst. Monographs, 1994, 16: 15-24, on p. 15. 


\section{Breast Cancer and the Politics of Abortion in the United States}

among women in low-income urban areas (53 per cent) and among African-American women (118 per cent), which contradicted the longstanding association between breast cancer and white, middle-class prosperity. As a possible explanation for the overall trend, they pointed to changes in reproductive patterns in the post-war period; as they noted, among American women "born between 1950 and 1954, 48\% were nulliparous at age 25 years, compared with $29 \%$ of women born between 1935 and 1939". ${ }^{26}$ In addition, they pointed out that many young women now delayed pregnancy through the use of oral contraceptives and abortion, both of which were under suspicion as risk factors, and that abortion rates were higher among black women than white women.

Daling and her colleagues were awaiting the results of a long-term study focused on abortion and cancer in young women which would cause a considerable stir once it was released. Meanwhile, the findings of other researchers contributed to the growing confusion. A Swedish study reported that, although the increase in abortion rates had paralleled a 40 per cent increase in breast cancer among women aged 20 to 44, they found no association between the two, while the study by Holly Howe and her colleagues in New York state reached the opposite conclusion. ${ }^{27}$ As for the rising incidence of breast cancer among young African-American women, an examination of this trend in the San Francisco Bay area found that breast cancer had been increasing in the African-American population throughout the post-war period, well before the legalization of abortion. ${ }^{28}$ A team in the eastern US concluded that there was some association between abortion and cancer in African-American patients diagnosed after the age of fifty, but that spontaneous abortion seemed to offer a small protective effect among the same group of women. ${ }^{29}$

By the early 1990s, the debate over the possible link between abortion and breast cancer was about to move beyond the pages of medical journals and into the public eye. This was not, as yet, because of a growing concern among clinicians; a study of physicians' perceptions of breast cancer risk conducted in southern California during 1991-2 revealed that none of those interviewed mentioned abortion among the twenty-nine potential risk factors listed. ${ }^{30}$ Instead, public awareness of the controversy would come in the wake of Janet Daling's new study, outlined below. Like others, this study had its flaws, and would not have received mass media coverage and aroused the interest of anti-abortion politicians if it were not for two factors. Firstly, the alarming claim that there was an epidemic of breast cancer in the United States, especially among younger women, had been widely reported in the early 1990s and had become an intensely political issue. Secondly, the anti-abortion campaign had reached a stage in its increasingly violent history when new strategies were needed, and activists recognized that an association between abortion and breast cancer could be very useful to their cause.

\footnotetext{
${ }^{26}$ White, et al., op. cit., note 24 above, p. 239.

${ }^{27}$ In 1989 , two widely published studies reported conflicting results concerning younger women. See Lindefors Harris, et al., op. cit., note 22 above, p. 1430; Howe, et al., op. cit., note 22 above, p. 300.

${ }^{28} \mathrm{~N}$ Krieger, 'Social class and the black/white cross over in the age-specific incidence of breast cancer: a study linking census-derived data to population-based registry', Am. J. Epidemiol., 1990, 131: 804-14, on pp. 804-5, 812 .
}

\footnotetext{
${ }^{29}$ A Laing, F M Demenais, R Williams, G Kissling, $\mathrm{V}$ Chen, and G Bonney, 'Breast cancer risk factors in African-American women: the Howard University Tumor Registry experience', J. Nat. med. Assoc., 1993, 85: 931-9.

${ }^{30}$ J M McMullin, L R Chavez, F A Hubbell, 'Knowledge, power and experience: variation in physicians' perceptions of breast cancer risk factors', Med. Anthropol., 1996, 16: 295-317, on p. 306.
} 


\section{Patricia Jasen}

\section{Cancer Epidemiology and the Abortion Wars}

During the same years as research into a possible abortion-breast cancer link was intensifying so, too, was the militancy of the anti-abortion movement. Fundamentalist Christianity and the New Right had become closely allied, but, after Republican Ronald Reagan was elected president in 1980, there was disappointment and a sense of betrayal, for the new administration did not seek to reverse Roe v Wade. In 1983 the Senate defeated an amendment that would have returned the abortion issue to the state level, and there continued to be about one and a half million abortions performed in the US each year. ${ }^{31}$ As the lobbying efforts of the non-violent majority in the movement seemed to have accomplished little, supporters of direct action rose to prominence, first employing tactics, such as sit-ins, inherited from the tradition of civil disobedience, but moving on by the mid-1980s to clinic break-ins and bombings. Carol Mason has analysed the rise of an apocalyptic narrative within the movement - the understanding that if abortion were not stopped, God would cease to protect America. ${ }^{32}$ The evangelical leaders Pat Robertson and Jerry Falwell gave their support to the violent strategies of such groups as Operation Rescue, and at the 1988 Democratic convention in Atlanta hundreds of demonstrators were arrested. But most politicians knew by that point that a majority of Americans had come to accept the right of adults to seek early abortion, and the newly elected Republican leader, the elder George Bush, would not commit his party-in his words - to a "litmus test" on the abortion question. ${ }^{33}$ The belief that they had once again been abandoned by the conservative establishment encouraged even more desperate measures on the part of anti-abortion activists, but the 1993 murder of the physician David Gunn irreparably harmed the movement. In 1994, President Clinton signed the Freedom of Access to Clinic Entrances Act (known as FACE), and the Supreme Court ruled that lower courts could establish "protestfree buffer zones" around abortion clinics. Arsons, bombings, and murders of clinic workers continued during that year, leading to the collapse of violent anti-abortion activism in the US. ${ }^{34}$ Organizations such as National Right to Life reasserted their leadership in the movement and pursued more targeted strategies, including opposition to late-term abortion (termed partial-birth abortion) and to FDA approval of the abortion drug RU-486. ${ }^{35}$ They also began to use the alleged abortion-breast cancer link to discourage women from abortion and to demand new legislation.

The widespread belief that a breast cancer epidemic was under way in the US seemed to substantiate the movement's theory that the "abortion generation"- -younger women who had become sexually active in the twenty years since Roe v Wade-were now reaping the consequences of their freedom to terminate pregnancies at will. ${ }^{36}$ The notion of an epidemic requires closer examination, for it arose largely from an inaccurate understanding of breast cancer history. It was true that there had been a moderate but steady increase in

\footnotetext{
${ }^{31}$ Risen and Thomas, op. cit., note 7 above, pp. 130, 241.

${ }^{32}$ Mason, op. cit, note 12 above, p. 4.

${ }^{33}$ Risen and Thomas, op. cit., note 7 above, p. 276.

${ }^{34}$ David Garrow, Liberty and sexuality: the right to privacy and the making of Roe $v$ Wade, Berkeley, University of California Press, 1998, pp. 705-14.
}

\footnotetext{
${ }^{35}$ Risen and Thomas, op. cit., note 7 above, pp. 373-6.

${ }^{36}$ For example, the president of Abortion Industry Monitor wrote that "Abortion... can explain many features of an otherwise mystifying worldwide breast cancer epidemic". See Scott W Somerville, 'Does abortion increase the risk of breast cancer?', J. Med. Assoc. Georgia, 1994, 83: 209-10, p. 210.
} 


\section{Breast Cancer and the Politics of Abortion in the United States}

breast cancer rates since the 1940s, but the more recent and alarming rise in diagnoses was in good part due to early detection through mammography. This conclusion was supported by the fact that the increase was seen mainly in the early stages of the disease, that the greater increase occurred not in young women but in those over fifty (the age group most likely to be effectively screened), and that rates had levelled off by the late 1990s, as would be expected if the increase were due to early detection. ${ }^{37}$ Paula Lantz and Karen Booth have examined the role played by the media in raising fears of an epidemic in the UShow the disease was portrayed as being out of control, and how the discussion of reproductive factors, such as birth control and delayed childbearing, underscored the frequent suggestion that it was young, white, "liberated" women who were in the greatest danger. Lantz and Booth found, for example, that 85 per cent of the case studies and anecdotes found in popular magazines described women who were under fifty, whereas only 20 per cent of those diagnosed were in that age group. The number of such articles increased dramatically during the 1990s, and, after 1993, induced abortion was added to the list of risk factors mentioned. Lantz and Booth propose that the portrayal of women as victims of their own behaviour may be seen in the context of a backlash against the power and autonomy that women had achieved through controlling their fertility, and it was certainly the case that anti-abortionist literature increasingly linked the fight against breast cancer with the struggle to preserve conservative "family values". 38

The most vocal proponent of an abortion-breast cancer link in the early 1990s was Joel Brind, a professor of biochemistry at Baruch College in New York City. His area of academic research had been the study of blood levels of steroids in relation to disease. In 1985, he experienced (in his words) "a major course correction" when he converted from Judaism to Christianity, and thereafter he sought to reconcile his professional life with his newfound religious conviction. Brind became involved with National Right to Life, and, wishing to devote his scientific expertise to the cause, he began by providing information on the steroid abortion drug, RU-486. Another turning point came when he read an article in Science News which discussed the most recent research of Malcolm Pike (who had drawn attention to abortion and cancer risk in young women back in 1981). This article focused on the apparent protection that pregnancy offered against breast cancer, but omitted to say that the pregnancy had to be full-term or to mention Pike's earlier findings regarding abortion. Now convinced that the link was real, that knowledge of it was "being actively suppressed", and that the Lord wished him to "bring this life-saving knowledge into public awareness", Brind protested, but Science News failed to publish his letter. Further efforts did not bring the recognition he desired, and his belief in a conspiracy of

\footnotetext{
${ }^{37}$ P M Lantz and K M Booth, 'The social construction of the breast cancer epidemic', Soc. Sci. Med., 1998, 46: 907-18, on pp. 907-8; S E King and D Schottenfeld, "The "epidemic" of breast cancer in the US-determining the factors', Oncology 1996, 10: 453-62; G Gigerenzer, Reckoning with risk: learning to live with uncertainty, London, Penguin, 2002, pp. 77-80. The National Cancer Institute confirmed that "No increases in breast cancer incidence were apparent in either black or white women less than 50 years old"; H L Howe, P A Wingo, M J Thun,
}

L A G Ries, H M Rosenberg, E G Feigal, B K Edwards, 'Annual report to the nation on the status of cancer (1973 through 1998), featuring cancers with recent increasing trends', J. Nat. Cancer Inst., 6 June 2001, 93: 824-42, on p. 827.

${ }^{38}$ Lantz and Booth, op. cit., note 37 above, pp. 910-17; see also D Lupton, 'Femininity, responsibility, and the technological imperative: discourses on breast cancer in the Australian press', Int. J. Health Services, 1994, 24: 73-89, on pp. 82-3. 


\section{Patricia Jasen}

silence — and his vision of his own messianic role-seem to have been born at this time. ${ }^{39}$ He began publishing regularly on this issue in the anti-abortion press, confident that his efforts would "spare many women the agony of breast cancer". 40

It was in this atmosphere of heightened tension and growing militancy that an article published in the Journal of the National Cancer Institute, along with its accompanying editorial, came to occupy centre stage in this debate. In the autumn of 1994, Janet Daling and her colleagues reported the findings of their much anticipated study of breast cancer in the generation of women "born recently enough to have had some or most of their reproductive years after the legalization of induced abortion". ${ }^{41}$ As was the case in most such studies, their methodology involved in-person interviews with cases and controls in order to collect detailed information on the women's reproductive histories. After attempting to take other risk factors into account, they found that, among women who had been pregnant at least once, those who had had an induced (but not a spontaneous) abortion had a 50 per cent higher risk of developing breast cancer before the age of $45(R R=1.5)$ than those who did not, and that the highest risk was associated with abortion in the last month of the first trimester $(\mathrm{RR}=1.9)$. Contrary to some previous studies, including that of Pike and his colleagues, they reported no difference in risk associated with the number of abortions or in women with completed pregnancies. Much would be made by Brind and others of the findings which concerned women who had aborted before the age of 18 . For this group, the relative risk was 9.0 if the abortion took place between 9 and 24 weeks of pregnancy, and all twelve of the women with a family history of breast cancer who had aborted before the age of 18 had later been diagnosed with breast cancer. But these categories represented less than 3 per cent of the total of 845 cancer cases, and the interpretation of such figures would also be complicated by the fact that cancer patients who had never had a completed pregnancy were being compared with a control group of parous women. ${ }^{42}$ Daling herself warned against reaching "a firm conclusion at the time". 43 In fact, Daling and her team published a study two years later which found that abortion was associated with a relative risk of only 1.2, that "there was no excess risk of breast cancer associated with induced abortion among parous women", and that there was no subgroup "in whom the relative risk associated with induced abortion is unusually high". 44 That report would go largely unnoticed.

\footnotetext{
${ }^{39}$ Joel Brind, 'Reading the data: defining a link between abortion and breast cancer', Physician Magazine, July/August 2000, pp. 1-7, on pp. 2-4. This journal no longer has a printed version, and can only be found online; the address is: http://www.family.org/ physmag/pastissues/A0012416.cfm (accessed 16 Oct. 2003). It was also circulated in pamphlet form by an organization called Focus on the Family. On the developing controversy involving Pike and others, see Troy Parkins, 'Does abortion increase breast cancer risk?', J. Nat. Cancer Inst., 15 Dec.1993, 85: 1987-8. Pike's research dealt with whether women could gain the protective effects of pregnancy through the use of hormones; for a critique, see Susan Rennie, 'Imagine the profits if half the healthy population were put on yet another drug', Ms., May/June 1993, 3: 42-6.
}

\footnotetext{
${ }^{40}$ Joel Brind's web page, Department of Natural Sciences Faculty website, Baruch College, City University of New York, http://www.baruch.cuny.edu/ wsas/departments/natural_science/faculty/brind.html (accessed 2 Nov. 2003).

${ }^{41}$ J R Daling, K E Malone, L F Voigt, E White, and N S Weiss, 'Risk of breast cancer among young women: relationship to induced abortion', J. Nat. Cancer Inst., 2 Nov. 1994, 86: 1584-92, on p. 1584.

${ }^{42}$ Ibid., pp. 1585-92.

${ }^{43}$ Daling, et al., op. cit., note 41 above, p. 1592.

${ }^{44} \mathrm{~J}$ R Daling, L A Brinton, L F Voigt, N S Weiss, R J Coates, K E Malone, J B Schoenberg, and M Gammon, 'Risk of breast cancer among white women following induced abortion', Am.J. Epidemiol., 15 Aug. 1996, 144: 373-80, on pp. 373, 375.
} 


\section{Breast Cancer and the Politics of Abortion in the United States}

The positive correlations Daling reported in 1994 would give proponents of the abortionbreast cancer link their strongest support to date, but, for Brind, the editorial that accompanied Daling's report was almost as important as the study itself. Written by Lynn Rosenberg of the Slone Epidemiology Unit at the Boston University School of Medicine, the editorial reflected some of the wider debates under way in the discipline of epidemiology in the 1990s, including the problem of recall bias inherent in retrospective studies, and the questionable statistical significance of fairly low elevations in risk. It also drew attention to some specific shortcomings and inconsistencies in Daling's study, and to the lack of a "convincing biologic mechanism" to explain why induced abortion posed a danger while spontaneous abortion did not. Acknowledging the "intensity of emotion" surrounding the issue, Rosenberg ventured that, while Daling's results provided leads for the scientific community, it was questionable how they would be "informative to the public" at that time. She concluded that "whatever future results show, the decision to continue or terminate an unplanned pregnancy will still need to be based on a balanced consideration of the entire range of relevant issues-personal ethical considerations, the desire for a child, the ability to care for it, and the total health implications of continued pregnancy versus induced abortion". "F5 For Brind, Rosenberg's efforts to defuse the issue gave credence to his repeated accusations that the National Cancer Institute was determined to cover up or discredit research pointing to an abortion-breast cancer link.

The publication of Daling's report and Rosenberg's response unleashed a reaction that put pro-choice advocates on the defensive. Time magazine reported that, months before the results were officially released, anti-abortionists "laid plans to trumpet the seven-year study's findings", while "in the opposition camp, pro-choice groups marshalled the statistics they needed" to defend their position. ${ }^{46}$ While the study was still in progress, Daling was pursued for days by a Virginia lawyer employed by a right-to-life group trying to recruit her as a spokesperson, and she recounted how she finally told him, "I don't think you care one bit about breast cancer and women's health". ${ }^{47}$ Once the report appeared, newspapers, magazines, and television news shows publicized the highlights, many cautiously, but some in a partisan fashion, either praising or criticizing the study. Daling herself repeatedly told the media that politics and personal views should not be allowed to cloud the issue, but it was inevitable that breast cancer would become a new weapon in the abortion wars. ${ }^{48}$ For example, Christ's Bride Ministries rented space in rapid-transit stations in the eastern US to advertise that "Women who choose abortion suffer more and deadlier breast cancer!" (wording which Brind helped choose), and the federal order to remove the posters in Philadelphia fuelled charges of a cover-up by Washington. ${ }^{49}$ Meanwhile, anti-abortionists in Congress began a long campaign demanding hearings on the abortion-breast cancer question, and more post-Reagan, New Right Republicans were drawn to the issue. Doubting the effectiveness of sheer denial on the part of pro-choice

\footnotetext{
${ }^{45}$ Lynn Rosenberg, 'Induced abortion and breast cancer: more scientific data are needed', J. Nat. Cancer Inst., 2 Nov. 1994, 86: 1569-70.

${ }^{46}$ Christine Gorman, 'Do abortions raise the risk of breast cancer?', Time, 7 Nov. 1994, 144: 61 .

${ }^{47}$ Ibid.
}

\footnotetext{
${ }^{48}$ Ibid.; R Rubin, 'Linking abortion and breast cancer', U.S. News and World Report, 7 Nov. 1994: 70 .

${ }^{49}$ Yeoman, op. cit., note 17 above, p. 59. The ads were removed in February 1996, but returned two years later following a higher court decision.
} 


\section{Patricia Jasen}

advocates in such a climate, the left-leaning magazine Mother Jones took the view that, by attacking Daling's study and dismissing its findings outright, "most pro-choice groups have played right into Newt [Gingrich]'s hands". 50

Meanwhile, researchers produced new studies and engaged in a growing international debate over methodological questions. Because retrospective studies still predominated, the question of recall bias remained highly relevant, especially in light of a Swedish study which suggested that it could result in a 50 per cent increase in reported risk. ${ }^{51}$ One method of investigating the influence of recall bias was to examine differences in responses among sub-groups of women involved in the studies. At the University of Wisconsin Comprehensive Cancer Center, Madison, Polly Newcomb found a higher level of risk for women who had abortions before 1973, suggesting a higher rate of underreporting among controls for the period when abortion was still illegal, while M A Rookus of the Netherlands Cancer Institute found a higher association between abortion and breast cancer in the mainly Roman Catholic south-eastern portion of the country, suggesting that Catholic women in the control group were more likely to under-report. ${ }^{52}$ Other researchers addressed the question of why so many studies, including Daling's, showed no increased risk following spontaneous abortion. The standard answer was that failed pregnancies were the result of hormonal deficiencies and did not affect breast tissue the same way. But a Greek research team pointed out that this was true only in some cases, and that a percentage of spontaneous abortions should have the same effect on cancer risk as induced abortions. If the data did not reflect that fact, then "subtle information bias" must be considered a possibility. ${ }^{53}$ Given the conflicting nature of the data thus far and the apparent problem of bias, the American Medical Association warned that legislative initiatives already under way in some states by 1995 must be considered premature. ${ }^{54}$

In Joel Brind's view, such caution was mere cowardice or compliance with a proabortion medical culture, and he heightened his efforts to reach a wider audience. He wrote frequently about the problem of denial, as he saw it, in the anti-abortion press, ${ }^{55}$ while continuing the fight against the legalization of RU-486, using the abortion-breast

\footnotetext{
${ }^{50}$ Bill Turque, 'Aborted revolution?', Newsweek, 12 Dec. 1994, 124: 38-40, on p. 40; Michael Castleman, 'Abortion's risk,', Mother Jones (March/April 1995), at http://www.motherjones.com/mother_jones/ MA95/castleman.html (accessed 3 Nov. 2003).

Neo-conservative Newt Gingrich became

Speaker of the US House of Representatives in January 1995.

${ }^{51}$ B M Lindefors-Harris, G Eklund, H O Adami, and $\mathrm{O}$ Meirik, 'Response bias in a case-control study: analysis utilizing comparative data concerning legal abortions from two independent Swedish studies', Am. J. Epidemiol., 1991, 134: 1003-8. See also E F Jones and J D Forrest, 'Underreporting of abortion in surveys of U. S. women: 1976 to 1988 ', Demography, 1992, 29: 113-26. Daling was involved in a later study which found no evidence of recall bias. See M T Tang, N S Weiss, J R Daling, and K E Malone, 'Case-control differences in the reliability of reporting a history of induced abortions', Am. J. Epidemiol., 2000, 151: 1139-43.
}

\footnotetext{
${ }^{52}$ P A Newcomb, B E Storer, M P Longnecker, R Mittendorf, E R Greenberg, and W C Willett, 'Pregnancy termination in relation to risk of breast cancer', J. Am. med. Assoc., 1996, 275: 283-7, on p. 286; M A Rookus and F E van Leeuwen, 'Induced abortion and risk for breast cancer: reporting (recall) bias in a Dutch case-control study', J. Nat. Cancer Inst., 4 Dec. 1996, 88: 1759-64.

${ }^{53}$ L Lipworth, K Katsouyanni, A Ekbom, K B Michels, and D Trichopoulos, 'Abortion and the risk of breast cancer: a case-control study in Greece', Int. J. Cancer, 1995, 61: 181-4, on p. 184; A Tavani, C La Vecchia, S Franceshci, E Negri, B D’Avanzo, and A Decarli, 'Abortion and breast cancer', Int. J. Cancer, 1996, 65: 401-5, on p. 404.

${ }^{54}$ M D Gammon, J E Bertin, and M B Terry, 'Abortion and the risk of breast cancer: is there a believable association?', J. Am. med. Assoc., 24-31 Jan. 1996, 275: 321-2, on. p. 322.

${ }^{55}$ See publications list, Joel Brind's website, op. cit., note 40 above.
} 


\section{Breast Cancer and the Politics of Abortion in the United States}

cancer link as part of his argument. When testifying at the FDA's advisory committee hearing in 1996, he predicted that "thousands upon thousands" of women would get breast cancer as a result of having used this drug. ${ }^{56}$ That year, Brind also published a lengthy review and meta-analysis of twenty-three studies dealing with induced abortion and cancer and thus entered into a dialogue with the epidemiological community. In his version of the history of the abortion-breast cancer debate, he described how a positive association had first been observed in Japan in 1957, and how, since then, such findings were consistently ignored or their validity questioned even by those who had conducted the research. He determined that, taken together, the studies proved that abortion raised the risk of cancer by at least 30 per cent. In his view, there was "overwhelming evidence" that recall bias was not a factor, and he used data from a variety of studies to argue that, while spontaneous abortion did not lead to higher cancer risk, induced abortion elevated risk irrespective of when it occurred in a woman's reproductive life. He concluded that the studies published thus far, whether prospective or retrospective, produced a very consistent, positive association between induced abortion and breast cancer independent from all other risk factors, including nulliparity. ${ }^{57}$ More studies might be useful, said Brind and his co-authors, but "there exists the more present need for those in clinical practice to inform their patients about what is already known". 58

The fact that Brind had gained a hearing through a reputable medical journal made him more difficult to ignore and affected the tenor of the debate in the wider research community. At least some researchers felt the need to respond directly to his challenge, while at the same time using this opportunity to confront the wider problem of bias as it affected their discipline. At the Harvard University School of Public Health, Karin Michels and Walter Willett conducted their own survey of the medical literature on abortion and breast cancer and concluded, unlike Brind, that the investigation to date did not permit a final assessment of the issue. ${ }^{59}$ When interviewed for the Harvard University Gazette, Michels pointed again to the problem of recall bias in retrospective studies, and questioned Brind's method of combining a series of reports and attempting to arrive at an overall estimate, "instead of trying to understand why the studies differ in their results". 60

\footnotetext{
${ }^{56}$ W Wright, 'The deceit behind RU-486: Who's really in control?', Family Voice, Nov.-Dec. 2000, p. 2, at http://www.cwfa.org/familyvoice/2000-11/ 14-19.asp (accessed 5 Jan. 2002).

${ }^{57}$ J Brind, V M Chinchilli, W B Severs, and Joan Summy-long, 'Induced abortion as an independent risk factor for breast cancer: a comprehensive review and meta-analysis', J. Epidemiol. Community Health, 1996, 50: 481-96. None of the authors was an epidemiologist. Severs and Summy-Long were endocrinologists and abortion opponents; Chinchilli was a statistician who later described how he tried to temper Brind's conclusions. See Yeoman, op. cit., note 17 above, p. 57.

${ }^{58}$ Brind, et al., op. cit., note 57 above, p. 495. There was some evidence that patients were being advised of the possible risk. See M M Henderson and A McTiernan, 'Clinical programs for breast cancer protection', in Basil Stoll (ed.), Reducing breast
}

cancer risk in women, Dordrecht, Kluwer Academic Publishers, 1995, p. 179; 'Letters to the Editor', regarding Lucille Canty, 'Breast cancer risk: protective effect of an early first full-term pregnancy versus increased risk of induced abortion', Oncol. Nurs. Forum, Nov.-Dec. 1997, 24: 1671-2.

${ }^{59} \mathrm{~K}$ B Michels and W C Willett, 'Does induced or spontaneous abortion affect the risk of breast cancer?', Epidemiol., 1996, 7: 521-28, on p. 521. For a similar study by a team at the American Cancer Society, see P A Wingo, K Newsome, J S Marks, E E Calle, S L Parker, 'The risk of breast cancer following spontaneous or induced abortion', Cancer Causes and Control, 1997, 8: 93-108.

${ }^{60} \mathrm{~W}$ J Cromie, 'No sure link between abortion and breast cancer', Harvard University Gazette, 24 Oct. 1996, http://www.news.harvard.edu/gazette/1996/ 10.24/NoSureLinkBetwe.html (accessed 24 March 2004). 


\section{Patricia Jasen}

Responding both to Brind and Michels, an editorial in the Journal of the National Cancer Institute asked how two reviews with the same objective could produce such different results, and posed the question of whether the problem of bias was a sign that epidemiology had "reached its limit". Recall bias was one issue, but another was what they termed "wish bias", or "the extent to which a reviewer believes a priori that the hypothesis is true". They were critical of Brind's meta-analysis and his "blurring of association with causation", and used his work as a case study in how epidemiologists must learn to recognize when biases are being reproduced in a succession of studies, and why this occurs. "Indeed", they concluded, "after this excursion into the issue of abortion, bias, and breast cancer, it seems our future has as much to do with human behavior as with human biology". 61

In this atmosphere of uncertainty, a major study which was free from the problem of recall bias was bound to gain attention. In 1997, the New England Journal of Medicine published the results of research by Mads Melbye and colleagues in Denmark, which used the Danish national registries of induced abortions and breast cancer cases to study a cohort of 1.5 million women born between 1935 and 1978. It reported that induced abortion carried a relative risk of 1.0, indicating that there was no link between abortion and breast cancer. ${ }^{62}$ Criticizing Brind directly, Melbye pointed out that he had relied almost entirely on case-control studies and had based his results on "a crude analysis of published odds ratios and relative risks with no attempt to incorporate the original raw data into a more sophisticated statistical analysis". ${ }^{63}$ The accompanying editorial by Patricia Hartge of the National Cancer Institute also attacked Brind, touted Melbye's study as definitive, and added fat to the fire by concluding that "a woman need not worry about the risk of breast cancer when facing the difficult decision of whether to terminate a pregnancy". ${ }^{64}$ But flaws in Melbye's research left that position open to attack. By his own admission, the fact that pre-1973 abortion information was not included could lead to an under-estimation of a link with breast cancer among older women. ${ }^{65}$ Other researchers noted, as well, that it was far too early to know what the breast cancer incidence would be for women in the study who were born as recently as the 1970s-an age group for which abortion rates would have been comparatively high. ${ }^{66}$ Brind and his followers would soon exploit these limitations to the full, but they were arguably less motivated by a quest for scientific credibility than by the imperatives of the anti-abortion cause. In Brind's words, following the publication of Melbye's report, his telephone "was ringing off the hook, mostly from pro-lifers who had signed onto the ABC link based on my witness and were now being barraged with tough questions about their new found anti-abortion argument that went bust". 67

\footnotetext{
${ }^{61}$ D L Weed and B S Kramer, 'Induced abortion, bias, and breast cancer: why epidemiology hasn't reached its limit', J. Nat. Cancer Inst., 4 Dec. 1996, 88: 1698-99.

${ }^{62}$ M Melbye, J Wohlfahrt, J H Olsen, M Frisch, T Westergaard, K Helweg-Larsen, and P K Andersen, 'Induced abortion and the risk of breast cancer', New Engl. J. Med., 9 Jan. 1997, 336: 81-5.

${ }^{63}$ Ibid., p. 84.
}

\footnotetext{
${ }^{64} \mathrm{P}$ Hartge, 'Abortion, breast cancer, and epidemiology', New Engl. J. Med., 9 Jan. 1997, 336: $127-8$.

${ }^{65}$ Melbye, et al., op. cit., note 62 above, p. 84 .

${ }^{66} \mathrm{~L}$ L Bartholomew and D A Grimes, 'Focus on primary care: the alleged association between induced abortion and risk of breast cancer: biology or bias?', Obstetric and Gynecological Survey, 1998, 53: 708-14.

${ }^{67}$ Brind, op. cit., note 39 above, p. 5.
} 


\section{Breast Cancer and the Politics of Abortion in the United States}

\section{The "ABC Link" and the "Woman-Centred" Strategy}

This final section of the paper will examine more closely how the so-called "ABC link" was incorporated into the strategy taken by anti-abortion activists after the collapse of direct action in the mid-1990s, a strategy still in use ten years later. Central to their rhetorical approach is the notion of informed consent- the argument that women have a right to know about the health risks associated with abortion, and that the link to cancer has been both irrefutably proved and deliberately concealed by the medical establishment. Elements of this phase of the campaign have included the founding of organizations, such as the Breast Cancer Prevention Institute, whose members speak publicly and testify on this issue whenever possible; extensive use of the internet to warn women against abortion; the use of pregnancy-counselling centres to spread the ABC message; lobbying efforts to secure allies in Washington and to pressure the National Cancer Institute to change its stance on the issue; campaigns for state legislation intended to delay or discourage abortion-such as "Women's Right to Know" laws; and the mounting of malpractice suits against abortion clinics and physicians with the intent of making them uninsurable.

All of these tactics are ostensibly directed towards breaking down a wall of silence which prevents women from knowing the truth. They also employ a common rhetorical strategy which gained steadily in importance as majority opinion in the US shifted towards a greater acceptance of reproductive choice. Instead of the exclusive emphasis on fetal rights and the portrayal of women who choose abortion as murderers, the newer "womencentred" strategy presents such women as the uninformed, unwitting victims of a proabortion culture and industry. ${ }^{6}$ While the focus on fetal rights appeared to disregard the needs and rights of women (and lost support as a result), this strategy presents itself as protective, sympathetic, forgiving, and ready to help the woman suffering psychological or physical harm resulting from her abortion. As Leslie Cannold observes, activists using this approach co-opt what they perceive as feminist rhetoric and depict themselves "as having an agenda-less desire" to defend women against patriarchal pressure and a medical establishment determined to conceal the truth. In addition, through its insistence that a majority of women who abort will suffer trauma or illness, it seeks to normalize "a catastrophic view of abortion". 69

A "woman-centred" approach has been Joel Brind's strategy from the beginning. After his meta-analysis proved ineffective in allaying the scepticism still dominant in the medical community, he broadened his efforts by founding the Breast Cancer Prevention Institute in 1999 in order to publicize, by his own account, "risk reduction strategies not widely known to the public and healthcare professionals". ${ }^{70}$ The BCPI website represents itself as a clearing house for new information on cancer risk, but its real purpose is to warn women about the ABC link who might otherwise "feel helpless and hopeless when it comes to their risk of developing breast cancer". ${ }^{71}$ In comparison with other sites focused on this issue, Brind's is a model of restraint, although it does appropriate the folded pink

\footnotetext{
${ }^{68} \mathrm{~L}$ Cannold, 'Understanding and responding to anti-choice, women-centred strategies', Reproductive Health Matters, May 2002, 10: 171-9.

${ }^{69}$ Ibid., electronic version, pp. 4, 6 .

70 'The development of the

Breast Cancer Prevention Institute',
}

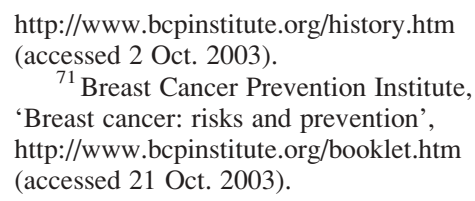

${ }^{71}$ Breast Cancer Prevention Institute, 'Breast cancer: risks and prevention', http://www.bcpinstitute.org/booklet.htm (accessed 21 Oct. 2003). 


\section{Patricia Jasen}

ribbon, the familiar symbol of breast cancer activism and fund-raising, to mark each link on its site navigation bar. The educational functions of the BCPI include public lectures and presentations at conferences, as well as the production of brochures, audio and video tapes, and commercials for public broadcast, including a television commercial called "I wish I had known". ${ }^{72}$ A common theme in all of its literature is the conspiracy of silence.

Closely associated with Brind is Angela Lanfranchi, a co-founder of the Breast Cancer Prevention Institute and its vice-president. As a female breast surgeon, Lanfranchi employs a woman-centred strategy to strong effect. In her portrayal of her own involvement with the issue, she recalls how, when she first heard of the abortion-breast cancer link, she thought it was a "pro-life fantasy". She then began asking her young cancer patients about their reproductive histories and found that some of them had indeed had abortions. Brind's 1996 meta-analysis then confirmed for her that the link was real. ${ }^{73}$ In a talk delivered on 14 November 2002 at Georgetown University, she related how she watched her mother die of breast cancer at the same time as she was realizing that cancer patients "were no longer post-menopausal grandmothers but young 30-year-old mothers with toddlers. I knew from my own painful experience what they would face". Identifying herself as part of the Roe v Wade generation and, at times, referring to women's "right" to end unwanted pregnancies, Lanfranchi claims to see the heartbreaking toll abortion takes in her practice "every day". 74

The Coalition on Abortion/Breast Cancer has goals similar to the Breast Cancer Prevention Institute, but is more openly devoted to the single cause. It was founded in 1999 by Karen Malec, a former teacher who, like Brind, has spoken widely and testified before government committees on this issue. ${ }^{75}$ Malec describes her coalition as a grassroots coming-together of cancer survivors and their families (she had been treated for colon cancer) and women who have had abortions. ${ }^{76}$ In fact, the coalition was founded with the support of Concerned Women for America, a national right-wing Christian organization which defines itself as anti-gay, anti-choice, anti-feminism and anti-sex education (as well as anti-Harry Potter) and actively lobbies for legislation recognizing the abortion-breast cancer link. ${ }^{77}$ The Coalition's advisory board includes Joel Brind; former US Congressman and medical doctor Chris Kahlenborn (author of Breast cancer: its link to abortion and the birth control pill (2000) and an opponent of all forms of artificial contraception);

\footnotetext{
${ }^{72}$ Breast Cancer Prevention Institute, 'Resources for breast cancer prevention', http://www.bcinstitute.org/resources.htm (accessed 21 Oct. 2003).

${ }^{73}$ Angela Lanfranchi, 'Breast cancer and abortion: the facts', The Age, 17 Feb. 2003, http://www.theage.com.au/articles/2003/02/16/ 1045330466585.html (accessed 22 March 2004).

${ }^{74}$ Angela Lanfranchi, 'Thirty years after Roe v. Wade, the abortion-breast cancer link, call to reason', delivered at Georgetown University, 14 Nov. 2002, http://suewidemark.com/abclinkmdtalk.htm (accessed 16 Oct. 2003).

${ }^{75}$ Coalition on Abortion/Breast Cancer, 'About us', http://www.abortionbreastcancer.com/About_Us.htm (accessed 10 Jan. 2004).
}

\footnotetext{
${ }^{76}$ Coalition on Abortion/Breast Cancer, 'The ABC summary: The coalition's history', http://www.abortionbreastcancer.com/ bc_summary.htm (accessed 23 June 2003).

${ }^{77}$ Catherina Hurlburt, Concerned Women for America, 'Spreading the truth about abortion', 8 Dec. 2000, http://www.cwfa.org/ articledisplay.asp? $\mathrm{id}=1454 \&$ department $=$ CWA\&categoryid=life (accessed 22 March 2004); People for the American Way, Right Wing Watch, Right Wing Organizations, http://www.pfaw.org/pfaw/ general/efault.aspx?oid=3151 (accessed $10 \mathrm{Jan}$. 2004); Margaret A Woodbury, 'Judge to rule on abortion, breast cancer link', Women's eNews, 17 Feb. 2002, http://www.womensenews.org/article.cfm/dyn/ aid/818/context/over/ (accessed 17 Jan. 2004).
} 


\section{Breast Cancer and the Politics of Abortion in the United States}

John Kindley, a lawyer who seeks out and represents women willing to sue abortion providers for not informing them of the cancer link; Charles Francis, an Australian lawyer who won the first successful malpractice suit of this kind; and his wife Babette Francis, who heads an organization allied with Malec's. ${ }^{78}$ The coalition's pink and blue logo consists of the words "Abortion Breast Cancer" printed over a large image of the folded pink ribbon, representing the organization's intent to co-opt an emotion-laden symbol and to supplant the breast cancer movement's influence or authority. ${ }^{79}$ The coalition's rhetoric is woman-centred, to the point of asserting that "women have the exclusive right to be decision makers where their own health care is concerned... we find it paternalistic that women have been prevented from making informed choices about this women's health issue". 80

Rescuing potential victims of misinformation is part of these organizations' mandate, and pregnancy counselling centres, whose purpose is generally to discourage abortion, can provide a venue for active intervention. Brind tells the story of how he received a call from a pregnancy-crisis centre in the Bronx, where the counsellor, having seen the BCPI website, was seeking help for a client. Thirty-one year old Juanita had been advised by her physician to have an abortion, which would have been her second, because she had been diagnosed with breast cancer. Brind referred her to Lanfranchi, who persuaded Juanita to carry the baby to term, and Brind credited himself with having saved her life. "For Juanita", he wrote, "not only did the abortion of her first pregnancy ... probably cause her breast cancer in the first place, but another abortion would likely seal her fate". ${ }^{81}$ The core of the problem was that Juanita's physician did not "know" that "a woman who is pregnant when diagnosed with breast cancer ... is much more likely to be cured if she has the baby, instead of an abortion". ${ }^{82}$ Brind's one source for this information was a Canadian study published in 1989, based on the records of 154 pregnant breast cancer patients treated at Toronto's Princess Margaret Hospital between 1931 and 1985, 21 of whom, in this 54-year period, had abortions and subsequently died. Its authors advised against abortion for such patients, but at the same time cautioned that treatment should be minimal in order to avoid harming the fetus. ${ }^{83}$ Not only is the study rife with methodological and ethical problems, but more credible studies have shown that, in most cases, abortion in itself neither worsens nor improves a patient's prognosis. They show that all such cases are profoundly complicated by intertwining social and medical implications. ${ }^{84}$

\footnotetext{
78 'About us', op. cit., note 75 above; see also John Kindley, 'Abortion, breast cancer, and informed consent', Issues in Law and Medicine, 2000, 15: 243-90.

${ }^{79}$ Catherina Hurlburt, 'If only she knew', Concerned Women for America-Family Voice, Sept.-Oct. 2000, 1, http://www.cwfa.org/ familyvoice/2000-09/16-21.asp (accessed 17 Feb. 2004).

80 'The ABC Summary', op. cit., note 76 above.

${ }^{81}$ Brind, op. cit., note 39 above, p. 6.

${ }^{82}$ Breast Cancer Prevention Institute, pamphlet titled 'The single most avoidable risk factor for breast cancer is ... elective abortion', n.d. http://www.bcpinstitute.org/brochure.htm.
}

\footnotetext{
${ }^{83} \mathrm{R}$ M Clark and T Chua, 'Breast cancer and pregnancy: the ultimate challenge', Clin. Oncol., 1989, 1: $11-18$

${ }^{84}$ See E M Murray and I D Werner, 'Pregnancy and abortion in breast cancer patients: two case reports and a literature review', S. Afr. med. J., 1997, 87: 1538-9; K M Gwyn and R L Theriault, 'Breast cancer during pregnancy', Curr. Treat. Options Oncol., 2000, 1: 239-43; N A Pavlidis, 'Coexistence of pregnancy and malignancy', Oncologist, 2002, 7: 279-87. The fiction that women "who have full term pregnancies after a diagnosis of breast cancer have a far better survival rate than those who do choose to abort" is maintained on the Abortion/Breast Cancer Coalition website, see http://www.abortionbreastcancer.com/news/031029/ (accessed 7 Jan. 2004).
} 


\section{Patricia Jasen}

A very public target of the anti-abortion movement has been the National Cancer Institute, not only for its dismissal of Daling's findings and uncritical support of Melbye's report, but also for the information supplied on its website, which potentially reaches millions of women around the world. After Melbye's study was published, the site's fact sheet asserted that "there is no convincing evidence of a direct relationship between breast cancer and either induced or spontaneous abortion". 85 The NCI came under sustained attack from Brind and his supporters, including those in Washington and, at a hearing into 'The State of Cancer Research' in July 1998, Congressman Tom Coburn (a leading advocate of abstinence-only sex education ${ }^{86}$ ) accused the NCI of concealing forty-one years of research demonstrating the existence of an abortion-breast cancer link. Political pressure led the agency to modify its web page the following year to say that the evidence was "inconsistent", but, under the administration of George W Bush, demands mounted in Congress for a further investigation, leading to another revision which suggested a much stronger association between abortion and cancer. ${ }^{87}$ Amidst a growing uproar, the NCI withdrew the fact sheet and scheduled a conference for February 2003, in order to revisit the issue. Pro-choice advocates attacked the agency for allowing abortion politics to drive the cancer research agenda, but when the majority of the assembled scientists, among them Daling, Rosenberg, Russo, and Melbye, reached an apparent consensus that "induced abortion is not associated with an increase in breast cancer risk", Brind and his supporters accused the NCI of a politically-motivated whitewash. ${ }^{88}$

Although proponents of the abortion-breast cancer link lobby under the banner of informed consent, their efforts clearly dovetail with other strategies employed in what has been called "the quiet war on abortion" during the past ten years. ${ }^{89}$ State legislation requiring mandatory waiting periods, parental consent, and specific counselling procedures has been sought since the 1970s as a means of circumventing the limits imposed by Roe $\mathrm{v}$ Wade, but such efforts intensified during the mid-1990s and quickly became associated with the issue of a breast cancer link. ${ }^{90}$ Within a year of the publication of Daling's report, legislation had been passed in two states and proposed in several others, either directing authorities to investigate the cancer link or taking the form of "Women's Right to Know"

\footnotetext{
${ }^{85}$ Life Lines News Archives, 'Pro-Life group urges boycott of breast cancer postage stamps', 1 March 2002, http://tennesseerighttolife.org/news_center/ archives/03012002-01.htm (accessed 7 Jan. 2004).

${ }^{86}$ Sexuality Information and Education Council of the United States, 'Former congressman Tom Coburn scheduled to co-chair presidential AIDS council', http://www.siecus.org/policy/PUpdates/Arch02/ arch020001.html (accessed 22 Jan. 2004).

${ }^{87}$ Lauren Slater, 'Did abortion cause my breast cancer?', Health, 6 Feb. 2004, 17: 142-5, on pp. 144-5.

${ }^{88}$ Beth Jordan, 'Weird science: if you want the truth about abortion and breast cancer, beware of the National Cancer Institute', Ms. Magazine (June 2003), http://www.msmagazine.com/june03/jordan.asp (accessed 2 Oct. 2003); Oregon Right to Life, Life in Oregon, 'Abortion/breast cancer link', April-May 2003, 11, 1, http://www.ortl.org/life_in_oregon/ 03_04/abortion_cancer_link.html (accessed
}

2 Oct. 2003). See also National Cancer Institute, 'Early reproductive events and breast cancer: workshop agenda, February 24-26, 2003', http:// www.cancer.gov/cancertopics/ere-workshop-agenda; Aaron Zitner, 'Health research being politicized, critics charge', Los Angeles Times, 23 Feb. 2003; Sally Squires, 'Study discounts link between abortion, breast cancer risk', Washington Post, 28 Feb. 2003, p. A11. For the NCI fact sheet as published after the conference, see National Cancer Institute, 'Abortion, miscarriage, and breast cancer risk,' Cancer Facts 03/21/2003, http://cis.nci.nih.gov/fact/3_75.htm.

${ }^{89} \mathrm{~B}$ Yeoman, 'The quiet war on abortion', Mother Jones (Sept.-Oct. 2001), http://www.motherjones.com/ news/feature/2001/09/abortion.html (accessed 24 March 2004).

${ }^{90} \mathrm{~W}$ Chavkin, 'Topics for our times: public health on the line-abortions and beyond', Am. J. Public Health, Sept. 1996, 86: 1204-6. 


\section{Breast Cancer and the Politics of Abortion in the United States}

acts requiring that women be advised of a possible cancer risk. ${ }^{91}$ The argument for parental consent laws, similarly, uses the danger of breast cancer to underscore the need for parents to be in control of their teenage daughters' health decisions. Such legislation is usually challenged, but statements made during the highly publicized court cases often enter into the rhetoric of the wider debate. A classic example of this process involved the suit by abortion providers against Florida's Parental Notification Law in 1999, which had already been twice struck down and revived. The case saw Joel Brind and Lynn Rosenberg as opposing expert witnesses, ${ }^{92}$ and, while the law was eventually overturned in 2003, both Brind's and Malec's organizations seized upon a portion of Rosenberg's testimony as evidence that "even Planned Parenthood's own expert" accepts that abortion posed a cancer risk for young women. ${ }^{93}$ In reality, Rosenberg had merely agreed under crossexamination that a pregnant 15 -year-old who aborts will have a higher life time risk of breast cancer than the adolescent who carries her baby to term and reaps the benefit of very early childbearing.

The mid-1990s also saw the emergence of lawsuits which had a similar goal of limiting access to abortion under the guise of ensuring informed consent. ${ }^{94}$ Early in 1995, the British Medical Journal noted the growing importance of malpractice suits in the US aimed at forcing abortionists out of business. The author described how an organization called Life Dynamics assembled evidence of the alleged harm caused to individual women following abortion, including the danger of breast cancer, while helping to link lawyers with potential clients. Their long-term goal was to establish the legal understanding that women could sue, even years later, for any adverse effects of abortion. Even though most malpractice suits of this kind have not been successful, abortion providers who win their cases may still be considered an actuarial risk and have difficulty obtaining insurance. ${ }^{95}$ American anti-abortionists have drawn encouragement from the recent settlement of an Australian suit based, in part, on the breast cancer link, ${ }^{96}$ and, in 2003, Concerned Women for America announced the first case won in the US on behalf of the parents of a young Philadelphia woman. The award included the cost of "regular medical screening for breast cancer and future counseling". 97

\footnotetext{
${ }^{91}$ Gammon, et al., op. cit., note 54 above, p. 322. The debate continues; see M Gallagher, 'Minnesota right to know brochure now includes abortion-breast cancer link', LifeNews.com (8 October 2003), http:// www.prolifeinfo.com/state177.html (accessed 30 Oct. 2003); J Elliott, 'Content of abortion information debated', Houston Chronicle, 21 October 2003.

${ }^{92}$ On this case, see Dave Andrusko, 'Parental Notification Laws pass in Texas and Florida', National Right to Life News, 10 June 1999, http://www.nrlc.org/ news/1999/NRL 699/bushes.html (accessed 24 March 2004); Bill Kaczor (Associated Press), 'Supreme court strikes down parental notice abortion law', 10 July 2003, http://www.ledger-enquirer.com/mld/ ledgerenquirer/news/local/6276407.htm (accessed 14 Sept. 2003).

${ }^{93}$ Joel Brind, 'ABC in the courts: dramatic ABC testimony in Florida's Parental Notification appeal,' Abortion-Breast Cancer Quarterly Update, Fall 1999,
}

2: 1; Joel Brind, 'An important crack in the wall of denial occurs in Florida Parental Notification case', National Right to Life News, 2000, http:// www.nrlc.org/news/2000/NRL03/brind.html (accessed 26 June 2004); Breast Cancer Prevention Institute, pamphlet, op. cit., note 82 above.

${ }^{94}$ Garrow, op. cit., note 34 above, pp. 715-16.

${ }^{95} \mathrm{~F}$ B Charatan, 'Abortion issue goes to U.S. courts', Br. med. J., 22 April 1995, 310: 1025-6, on p. 1025 .

96 'Coalition on abortion/breast cancer applauds Australian settlement', Life Lines News, 31 Dec. 2001, Archives, http://tennesseerighttolife.org/news_center/ archives/12312001-02.htm (accessed 26 Jan. 2004).

${ }^{97}$ R Rubin, 'Abortion and breast cancer: interpreting research makes debate difficult, a real “trial” impossible', USA Today, 1 March 2001, p. 9D; $\mathrm{P}$ Wong, 'Abortionist settles in landmark malpractice 


\section{Patricia Jasen}

In addition to suits involving individual practitioners, clinics have also been targeted for failing to inform women of the breast cancer link. The first and most widely publicized case of this kind began in 1999, and its three and a half year history involved many of the major players on both sides of the conflict. A false advertising suit was filed against Red River Women's Clinic in Fargo, North Dakota, for stating in its information brochure (based on the National Cancer Institute's 1996 fact sheet) that medical research did not support claims that abortion increases breast cancer risk. ${ }^{98}$ The suit was filed by Amy Jo Mattson, variously referred to as a "sidewalk counselor" and an anti-abortion activist serving as a "front person for the antis" who were using the case as a testing ground. ${ }^{99}$ Active supporters included the local pregnancy crisis centre and the Fargo Catholic Diocese, which had originally prompted the clinic to make the statement in question by placing billboards along the interstate highway asking: "'What increases your risk of breast cancer?' 'Abortion'". ${ }^{100}$ Mattson was represented by John Kindley, who was engaged in a similar case in San Diego. If successful, explained Kindley, such a suit could "open the abortion industry up to hundreds of tobacco-like lawsuits... There are millions of women with potential causes of action out there". ${ }^{101}$ The clinic was represented by Linda Rosenthal, on behalf of the Center for Reproductive Law and Policy based in New York City. ${ }^{102}$ While the suit, on the surface, had to do with the nature of informed consent, in the clinic's view its covert goals were "to scare women out of getting abortions and drain clinic resources" through legal expenses. ${ }^{103}$ The case finally went to trial in March 2002. Lynn Rosenberg was among the expert witnesses called by the defence, while the plaintiff's side relied on the testimony of Joel Brind. Once again, Daling's 1994 study competed with Melbye's 1997 report for credibility in the courtroom, and the scientific integrity of the National Cancer Institute was once more at issue. After a three-day trial, the judge ruled in favour of the defendant and also declared it reasonable that the clinic rely on the conclusions of authorities such as the NCI. ${ }^{104}$ Mattson appealed the decision to the North Dakota Supreme Court, which upheld the original decision. Proponents of the abortion-breast cancer link were vocal in their disappointment. "The court's decision stripped women of their right to informed consent", Malec protested. "Women will die and children will lose their mothers

suit', Concerned Women for America, 19 Nov. 2003, http://www.cwfa.org/articledisplay.as?id= 4898\&department $=$ cwa\&categoryid $=$ life (accessed 17 Jan. 2004).

${ }^{98} \mathrm{M}$ A Woodbury, 'Judge to rule on abortion, breast cancer link', Women's eNews, 17 Feb. 2002, http:// www.womensenews.org/article.cfm/dyn/aid/818/ context/cover/ (accessed 7 Jan. 2004).

${ }^{99} \mathrm{~K}$ J Lopez, 'Who cares about women's health?', NR Comment 1/22/01, http:// www.nationalreview.com/nr_comment/ nr commentprint012201a.html (accessed 2 Nov. 2003); Linda Rosenthal, 'North Dakota Supreme Court to consider abortion-breast cancer scare tactic', Center for Reproductive Rights, 16 June 2003, http://www.crlp.org/crt_cen_brstcancerqa.html (accessed 2 Nov. 2003).

100 'Update: judges rules no link between abortion and breast cancer', Minnesota Women's Press, Inc.,
27 Mar. 2002, http://www.womenspress.com/ newspaper/2002/18-1rrwc.html (accessed 2 Nov. 2003).

${ }^{101} \mathrm{~J}$ Torres, 'Abortion industry: the next target of tobacco-like lawsuits?', CNSNews.com, 9 Aug. 2000, http://www.cnsnews.com/Nation/ Archive/NAT20000809d.html (accessed 11 April 2005).

${ }^{102}$ For briefs and other documents relating to the defense, see Center for Reproductive Rights, 'Abortion breast cancer scare tactics', 2 Nov. 2003, http://www.crlp.org/crt_cen_cancer.html (accessed 2 Nov. 2003).

103 'Update: judge rules no link', op. cit., note 100 above.

${ }^{104}$ Center for Reproductive Rights, 'Judge rejects abortion-breast cancer scare tactic', CRR Press, 28 March 2002, http://www.crlp.org/ pr_02_0328ND.html (accessed 31 Oct. 2002). 


\section{Breast Cancer and the Politics of Abortion in the United States}

because the abortion industry is consistently pro-death". ${ }^{105}$ There was some gratification, however, in the attention the case and the wider issue had received. The Los Angeles Times, reporting on the trial, had described the furore over the cancer link as "the ferocious new front line in the abortion wars". 106

In the early years of the twenty-first century, however, the weight of medical evidence, some of which has emerged from countries where abortion is extremely common, continues to shift away from an association between abortion and breast cancer. ${ }^{107}$ Very recently, members of the Collaborative Group on Hormonal Factors in Breast Cancer, based at Radcliffe Infirmary in Oxford, published the results of a massive re-analysis of available data, which failed to confirm a link with abortion. ${ }^{108}$ Both the American College of Obstetricians and Gynecologists and its counterpart in the United Kingdom have responded to the ongoing campaign to link abortion and breast cancer by declaring publicly that, although the search for better methodological approaches to the question continues, there is no evidence at present to justify further anxiety over the issue. ${ }^{109}$ Even though proponents of the abortion-breast cancer link have lost credibility in the international research community, their campaign continues to gain willing converts, influence abortion legislation in a number of US states, and raise painful questions for women facing breast cancer or difficult reproductive choices. "Did I deserve my disease?" asked one American journalist, after a double mastectomy at the age of thirty-eight. Anxious to learn more about abortion and breast cancer, she spoke to individuals on both sides of the controversy, and, not surprisingly, received unequivocal yet completely opposing responses from both Brind and Rosenberg. From her perspective, there is no certainty or clarity, just a stronger awareness of the basic truth, in her words, that "science and ideology" are "hopelessly intertwined". 110

\section{Conclusion}

The abortion-breast cancer debate provides a particularly vivid illustration of how a variety of narratives may become intertwined in the complex history of medical risk.

\footnotetext{
${ }^{105} \mathrm{~S}$ Ertelt, 'Group condemns decision to dismiss abortion-breast cancer suit', LifeNews.com 28 September 2003), http://www.lifenews.com/ nat139.html (accessed 2 Nov. 2003).

${ }^{106} \mathrm{D}$ Andrusko, 'Abortion-breast cancer connection beginning to have its day in court', 2002, http://www.nrlc.org/news/2002/NRL04/dakota.html (accessed 18 Feb. 2004).

${ }^{107}$ For example, see M Sanderson, X O Shu, F Jin, Q Dai, W Wen, Y Hua, Y T Gao, and W Zheng, 'Abortion history and breast cancer risk: results from the Shanghai breast cancer study', Int. J. Cancer, 2001, 92: 899-905; G Erlandsson, S M Montgomery, $\mathrm{S}$ Cnattingius, and A Ekbom, 'Abortions and breast cancer: record-based case-control study', Int. J. Cancer, 2003, 103: 676-9; X Paoletti and F Clavel-Chapelon, 'Induced and spontaneous abortion and breast cancer risk: results from the $\mathrm{E} 3 \mathrm{~N}$ cohort study', Int. J. Cancer, 2003, 106: 270-6.

${ }^{108}$ Collaborative Group on Hormonal Factors in Breast Cancer, 'Breast cancer and
}

abortion: collaborative reanalysis of data from 53 epidemiological studies, including 83,000 women with breast cancer from 16 countries', Lancet, 27 March 2004, 363: 1007-16. They also revisited the question of bias, in order to examine the effect of recall bias (by analysing retrospective and prospective studies separately), and to reduce the effect of publication bias (by including the results of unpublished studies).

${ }^{109}$ Committee on Gynecologic Practice, American College of Obstetricians and Gynecologists, 'ACOG committee opinion. Induced abortion and breast cancer risk', Int. J. Gynecol. Obstet., 2003, 83: 233-5. In the UK, controversy erupted when the actuary Patrick Carroll published the results of a study by LIFE, an antiabortion group. See BBC News, 'Anger over abortion cancer study', 5 Dec. 2001, http://news.bbc.co.uk/1/hi/ health/1692144.stm (accessed 28 April 2004);

P Carroll, abortion and other pregnancy-related risk factors in female breast cancer, London, Pension and Population Research Institute, 2001.

${ }^{110}$ Slater, op. cit., note 87 above, pp. 144, 215. 


\section{Patricia Jasen}

Arising, at first, out of the post-war study of reproductive factors and breast cancer, the question of how abortion might affect cancer risk became more open to study after the procedure was legalized in many countries in the 1960s and 1970s. In the US, the aftermath of Roe v Wade coincided with the rise of evangelical Christianity as a major social and political force, and epidemiological research soon became a weapon in the wider struggle over abortion. As the conflict intensified and anti-abortionists replaced violent strategies with a more acceptable "woman-centred" approach, they adopted the "ABC link" as a means of fighting abortion in Congress, state legislatures and courts of law. Epidemiologists were inevitably drawn into the war of words and found themselves losing control over how their results were interpreted or put to use. As a by-product of this process, they were also provoked into a closer examination of how various kinds of bias operate within their own discipline, and why apparently similar studies may produce dramatically different results. Ironically, however, it is not only the methodologies underlying contradictory conclusions which need closer examination, but also the processes which allow studies to keep replicating results which are later discredited. An historical approach has much to offer in this regard. For example, an analysis of how a series of researchers interprets the existing literature concerning a potential risk factor provides insights into how quickly the specific nature of earlier studies slips from view, and how tentative conclusions may become fossilized or reified as citations accumulate. As the literature grows, the methods and results of studies are influenced by the developing epidemiological narrative, at the same time as they are also affected by the wider historical contexts in which the research questions have come to light, been deemed worthy of investigation, and been subsequently shaped or altered by social pressures. The abortion-breast cancer debate has been particularly complex because of the medical, social, and political significance of a dread disease seemingly out of control, and because of the emotional intensity surrounding the entire history of the conflict over abortion in the United States. The inseparability of science from social context confronts all those who attempt to find their way through the maze of conflicting evidence, motives, aims and strategies that have characterized this debate, whether they are epidemiologists, historians, clinicians, or the women whose health is at the heart of the question. 